\title{
Consensus
}

Volume 28

Issue 2 Spirituality and Health

Article 24

$11-25-2002$

\section{The New Dictionary of Pastoral Studies}

Thomas O'Connor

Follow this and additional works at: http://scholars.wlu.ca/consensus

\section{Recommended Citation}

O'Connor, Thomas (2002) "The New Dictionary of Pastoral Studies," Consensus: Vol. 28 : Iss. 2 , Article 24.

Available at: http://scholars.wlu.ca/consensus/vol28/iss2/24

This Book Reviews is brought to you for free and open access by Scholars Commons @ Laurier. It has been accepted for inclusion in Consensus by an authorized editor of Scholars Commons@ Laurier. For more information, please contact scholarscommons@wlu.ca. 
Rutledge has an engaging style well suited to print. Many of her sermons do not read like addresses but rather as devotionals shared at a family gathering. All the more remarkable, then, is her ability to convey orthodox dogmatic truth in an inspirational format. Rutledge is able to craft sermons that bring the timeless truths of Holy Writ to bear on the distinct needs of modern people. She makes no attempt to hide her orthodoxy, choosing to remain relentlessly monergistic and Christocentric throughout her work. To that end, she is not afraid to say the unfashionable thing. Furthermore, there is also present a deep concern for the hurting and distraught in these sermons. Rutledge holds nothing back, zeroing in on the reality of sin and the sorry human condition it has wrought. However, she is even more emphatic as she expounds on God's gracious response to human darkness, presenting Gospel hope for thirsty souls. The cross, for Rutledge, will always possess capacity to comfort, since, as she avers, "the cross is backlit by the dawn of God's new day."

The Undoing of Death is a fine companion for Holy Week devotions and makes a welcome additional resource for sermon preparation. It is a most unusual collection for our time, for it shows in a luminous manner that the cross, no matter how unpopular, will not been emptied of its power.

Jim Keller

St. Peter's Evangelical Lutheran Church

(Lutheran Church - Canada)

New Hamburg, Ontario

\section{The New Dictionary of Pastoral Studies}

Wesley Carr et al, ed.

Grand Rapids, MI: Eerdmans, 2002

432 pages, $\$ 50.00$ Hardcover

In the Introduction to The New Dictionary of Pastoral Studies, Welsey Carr outlines a number of goals for the book. This volume is designed for those who are not experts in pastoral studies but are beginning in the field. It is also designed for others who need a short summary of a particular topic. The dictionary seeks to fall mid-way Published by Scholars Commons @ Laurier, 2002 
between those dictionaries that provide long and original presentations on subjects and other dictionaries that provide a short summary on a subject. The book seeks to integrate theology with sociology, psychology and the other social sciences. However, Carr is forthright in stating that this dictionary works from a theological perspective. He maintains that the coordinating theme throughout the book is the word "pastoral" (xvii). The book succeeds mostly with these goals.

This dictionary of pastoral studies has over 700 entries by 200 contributors. Contributors are limited to the English speaking countries. The largest group of contributors is from the British Isles, with England dominating. Articles begin with a concise definition of the word or subject. An explanation and discussion follow this clarification. If there are divergent views on a subject, often the variety is presented. The concise definition is put in bold print at the beginning. The articles usually contain words that are further explained in other sections in the dictionary. These cross-listed words are underlined so that the reader can look up these words for further understanding.

There are many strengths to The Dictionary of Pastoral Studies. The short and concise definitions are helpful. The many entries are well written and there is a balanced approach to the entries. The authors offer excellent summaries of positions and are most often comprehensive in these. I have consulted with non-experts and they have found this dictionary helpful. At the same time, the various experts from different countries give the book a welcome international flavour. The areas that are given more in-depth study especially standout. One weakness of this dictionary is that it does not make any reference to the Dictionary of Pastoral Care and Counselling, edited by Rodney Hunter. I have found that dictionary, published in 1992, helpful. Within Carr's schema, it could be included as one of those dictionaries that have long and original presentations on a subject. Unfortunately, there is no mention of that book at all! The Dictionary of Pastoral Studies lacks journal articles in its bibliography. Some shorter articles don't identify the author. Better scholarship would have provided a comprehensive bibliography and would have identified authors of shorter articles. One subject, "praxis", is poorly done and does not reference any of the work done in Canada and the United States on this. Praxis is the core of pastoral studies, at least, in Canada. Finally, as a Canadian, I wanted more Canadian contributors. 
Certainly, the work by Wesley Carr, the associate editors and the many contributors in putting together The Dictionary of Pastoral Studies is a Herculean task. As he admits in the Introduction, there is no perfect dictionary. I disagreed with some presentations and lamented that others were missing. However, I give it an eight out of ten. It will certainly occupy an important place on my shelf.

Thomas St. James O' Connor, ThD

Assistant Professor, Pastoral Care and Counselling

Waterloo Lutheran Seminary

\section{Thomas Merton and the Monastic Vision}

Lawrence S. Cunningham

Grand Rapids, MI: Eerdmans, 1999

228 pages, $\$ 24.95$ Softcover

Given the overabundance of "mertonia" that has emerged since his death in 1968, sorting through the many books, articles, videos, tapes, monographs, etc, to obtain an accurate rendering and thoughtful analysis of Thomas Merton's life can be a daunting task indeed. Lawrence Cunningham has written a brief but thorough study of Merton's life and thought that offers an excellent introduction to his writings and influence in twentieth century religious life.

Cunningham places Merton in the context of both the early monastic Fathers and Mothers, whose influence played an important role in his development as a monk, and the vast changes of the Second Vatican Council amidst the social and political upheavals of the 1960's. As committed as Merton was to peace issues and the civil rights movement, his involvement grew out of a profound engagement with monastic tradition and his life as a contemplative monk. This brings me to Cunningham's thesis:

...the prolific works which flowed from Merton's pen and the impact that those writings and his person had and continue to have can only be understood against the background of his contemplative experience as a 